\title{
Peningkatan Kinerja Usaha Kecil dan Menengah (UKM) Kluster Kerajinan di Kota Depok Menggunakan The House Model
}

\author{
Putri Wahyuningrum \\ Departemen Manajemen, Fakultas Ekonomi dan Manajemen \\ Institut Pertanian Bogor \\ Kampus Dramaga Bogor 16680 \\ Anggraini Sukmawati \\ Departemen Manajemen, Fakultas Ekonomi dan Manajemen \\ Institut Pertanian Bogor \\ Kampus Dramaga Bogor 16680 \\ e-mail: anggrainism@gmail.com \\ Lindawati Kartika \\ Departemen Manajemen, Fakultas Ekonomi dan Manajemen \\ Institut Pertanian Bogor \\ Kampus Dramaga Bogor 16680
}

\begin{abstract}
Small Medium Enterprises (SMEs) of handycraft cluster is a business entity that produces products highly dependent on the skills of the craftsmen. In other words, human capital and social capital have an important role in improving the performance of handycraft cluster SMEs. Ishikawa Diagram analysis results stated that the main problem of SMEs's low performance derived from human resources factor. However, these results are contratry to the Importance-Performance Analysis results. SMEs owners pay more attention to improve infrastructure. It is this misperception which needs to be amened by improving the performance of SMEs handycraft cluster in Depok with the House Model's.

Keyword : handicraft, Ishikawa Diagram analysis, Importance-Performance Analysis, SMEs's performance, the House Model
\end{abstract}

\begin{abstract}
ABSTRAK
Usaha Kecil Menengah (UKM) Kluster kerajinan adalah entitas usaha yang menghasilkan produkproduk yang sangat bergantung pada keahlian tenaga pengrajin yang tersedia. Dengan kata lain, modal insani dan modal sosial memiliki peran penting dalam pengembangan kinerja UKM kluster ini. Hasil analisis Diagram Ishikawa menyatakan bahwa permasalahan utama dari rendahnya kinerja UKM berasal dari faktor sumberdaya manusia. Namun, hasil ini bertentangan dengan hasil Importance-Performance Analysis. Pemilik UKM lebih mementingkan sarana prasarana untuk diperbaiki. Oleh karena itu, kesalahan persepsi inilah yang perlu diperbaiki melalui rancangan peningkatan kinerja UKM kluster kerajinan Kota Depok dengan The House Model.

Kata kunci : kinerja UKM, kerajinan, modal insani, modal sosial, Structural Equation Modeling, the House Model
\end{abstract}

\section{Pendahuluan}

Usaha Kecil dan Menengah (UKM) telah terbukti memberikan kontribusi positif yang signifikan terhadap upaya-upaya penanggulangan masalah-masalah ekonomi dan 
sosial di Indonesia. Usaha Kecil yang dimaksudkan adalah perusahaan atau industri yang memiliki jumlah tenaga kerja 5 sampai dengan 19 orang, sedangkan Usaha Menengah merupakan perusahaan atau industri yang memiliki tenaga kerja 20 sampai dengan 99 orang (Tambunan 2009). UKM memiliki peran penting dalam menyediakan lapangan pekerjaan. Hal ini juga berlaku bagi UKM di Kota Depok. Sudarno (2012) menyatakan bahwa penduduk Depok pada tahun 2011 mencapai 1756565 orang. Dari jumlah tersebut yang termasuk angkatan kerja mencapai 730924 orang dan UKM sendiri berhasil menyerap angkatan kerja sebesar 543500 orang atau sekitar 73\%.

Kajian Dewan Perwakilan Rakyat Daerah (DPRD) dan Bagian Ekonomi Pemerintahan Kota Depok tahun 2011, memperoleh hasil bahwa potensi UKM Kota Depok harus dikembangkan ke arah industri kreatif. Lebih lanjut, Pemerintah Kota Depok telah membuat Grand Design UKM se-Kota Depok, yakni mengenai pengembangan beberapa kluster. Salah satu kluster yang fokus dikembangkan adalah kluster kerajinan karena memiliki kontribusi yang besar terhadap perekonomian Depok. Pada tahun 2011, industri kreatif berhasil menyumbang Rp 1.19 trilyun dari 6.95 trilyun Pendapatan Domestik Regional Bruto (PDRB) Kota Depok dan 30.36\% dari nilai tersebut berasal dari kluster kerajinan (Pemkot Depok 2012). Kontribusi klusterkluster industri kreatif terhadap Pendapatan Domestik Regional Bruto (PDRB) Kota Depok tahun 2011 dapat dilihat pada Gambar 1.

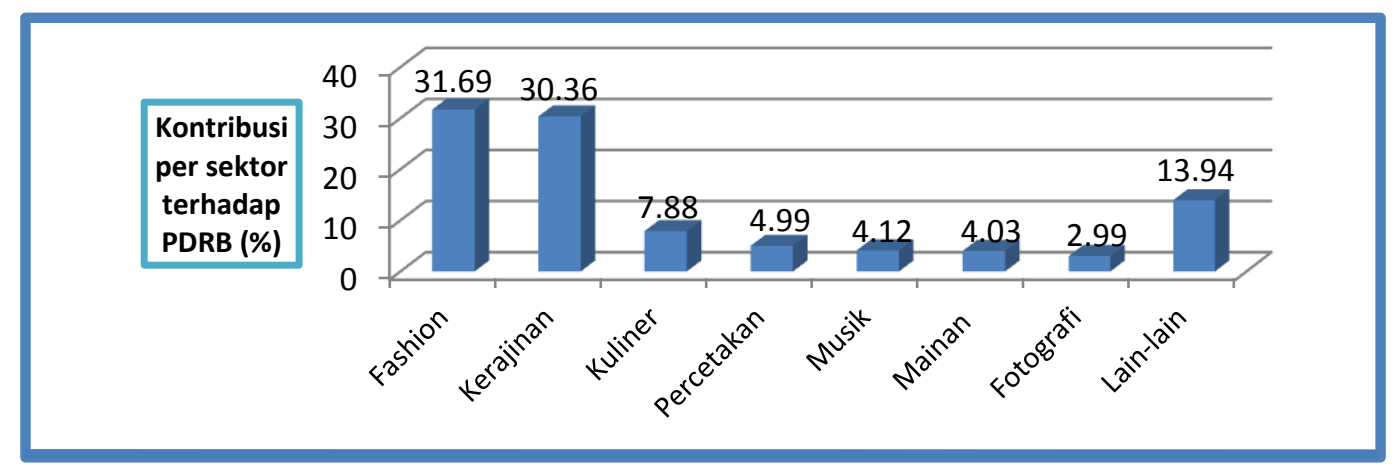

Gambar 1. Kontribusi kluster-kluster industri kreatif terhadap PDRB Kota Depok tahun 2011 (Pemkot Depok 2012)

Kontribusi UKM kluster kerajinan masih menempati posisi kedua terhadap PDRB Kota Depok, setelah kluster fashion. Hal ini disebabkan berbagai permasalahan yang dihadapi. Permasalahan yang dihadapi oleh UKM kluster kerajinan Kota Depok membuat kinerjanya menjadi tidak maksimal. Kinerja organisasi adalah keluaran yang dihasilkan oleh fungsi-fungsi atau indikator-indikator suatu pekerjaan atau suatu profesi dalam waktu tertentu (Wirawan 2009). Menurut Mayo yang disitasi Endri (2010), selama ini peningkatan kinerja lebih banyak dikaitkan dengan sumber daya yang bersifat fisik (tangible asset). Peningkatan kinerja perusahaan dari perspektif fisik dan keuangan sangatlah akurat tetapi sebenarnya yang menjadi penggerak nilai dari kedua perpektif tersebut adalah kemampuan yang dimiliki oleh sumberdaya manusia (intangible asset).

Tujuan penelitian ini adalah : 1) Mengidentifikasi permasalahan yang dialami oleh UKM kluster kerajinan di Kota Depok; 2) Menganalisis perbandingan tingkat 
kepentingan dengan kinerja yang telah dicapai UKM kerajinan Kota Depok; 3) Menganalisis rancangan model indikator utama dari peningkatan kinerja UKM kluster kerajinan di Kota Depok dan 4) Menganalisis faktor-faktor pendorong dan penghambat dari upaya peningkatan kinerja UKM kluster kerajinan di Kota Depok.

\section{Metode Penelitian}

Penelitian ini dilakukan melalui empat tahap, yaitu tahap pertama, mengidentifikasi permasalahan utama yang dihadapi UKM kluster kerajinan menggunakan diagram Ishikawa (fishbone chart). Hasil dari tahap pertama menjadi faktor-faktor yang dibandingkan pada tahap kedua menggunakan alat analisis Importance-Performance Analysis (IPA). Tahap ketiga, hasil yang diperoleh dari tahap pertama dan tahap kedua digunakan sebagai input dalam perancangan model peningkatan kinerja UKM dengan The House Model. Tahap terakhir adalah memberikan beberapa implikasi manajerial melalui Force Field Analysis (FFA). Kerangka pemikiran tersebut dijabarkan dalam Gambar 2.

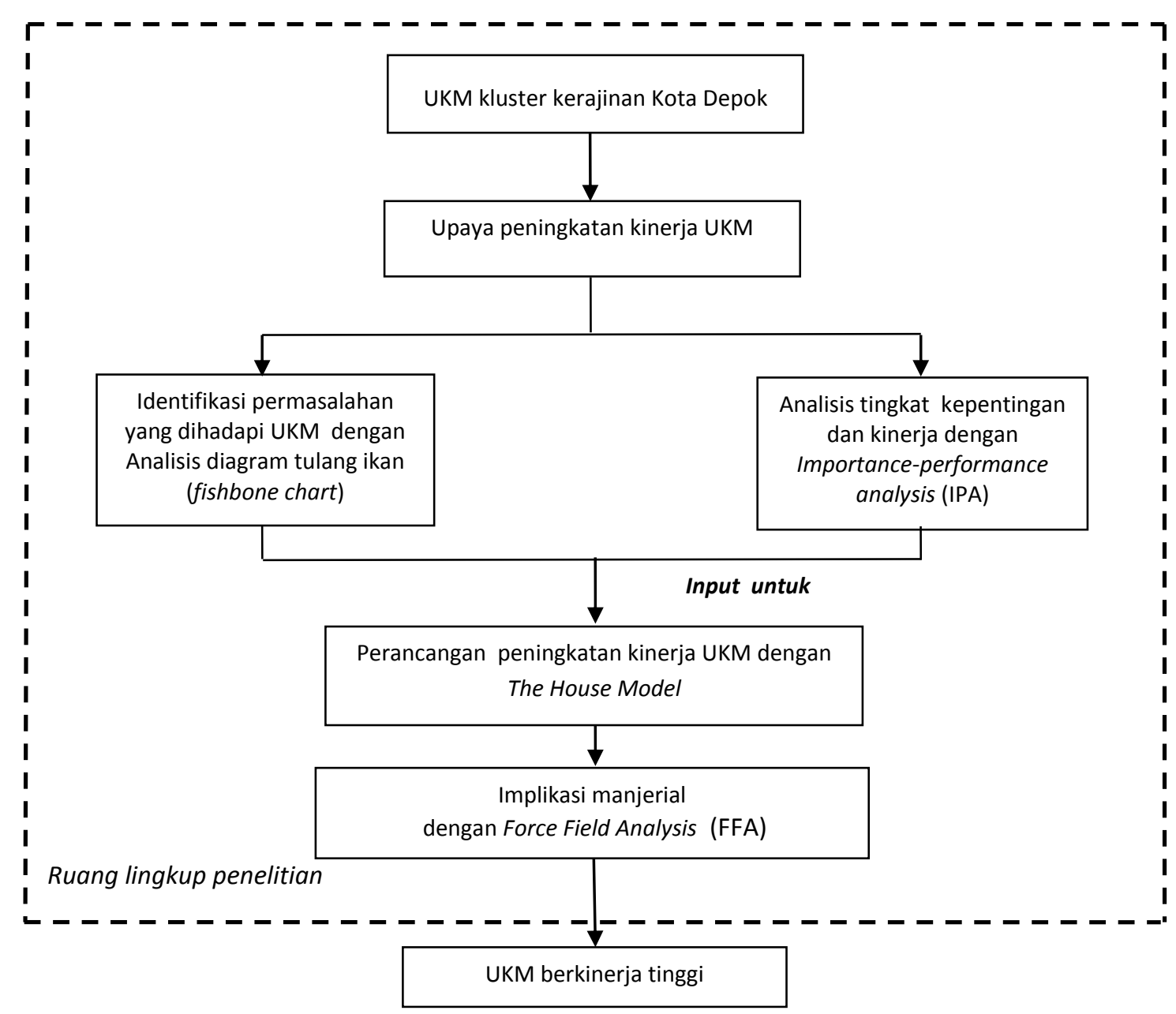

Gambar 2. Kerangka pemikiran penelitian 
Penelitian dilaksanakan di UKM kluster kerajinan di Kota Depok sejak Maret hingga Juli 2013. Jumlah populasi UKM Kerajinan di Depok adalah 18 UKM (Sudarno 2012). Teknik penentuan sampel yang digunakan adalah convenience sampling dan diperoleh 9 UKM yang menjadi responden penelitian.

Uji validitas dan reliabilitas kuesioner dilakukan kepada 30 responden pertama. Hasil uji validitas karyawan pada taraf signifikasi korelasi $5 \%$ menyatakan bahwa seluruh item valid. Uji reliabilitas yang digunakan dalam penelitian ini adalah dengan uji statistik Cronbach Alpha. Suatu konstruk atau variabel dinyatakan reliabel jika nilai Cronbach alpha $>0.60$. Hasil uji reliabilitas kuisioner karyawan pada penelitian ini menyatakan bahwa nilai cronbach's alfa dari seluruh variabel adalah 0.876 . Kesimpulannya, seluruh pertanyaan dari penelitian ini reliabel.

Metode analisis data yang digunakan dalam penelitian ini dijabarkan sebagai berikut :

1. Analisis Diagram Ishikawa

Diagram ini disebut juga diagram tulang ikan (fishbone chart). Menurut Prawirosentono (2007), konsep dasar dari diagram tulang ikan adalah permasalahan mendasar diletakan di bagian kanan dan penyebab permasalahan digambarkan pada sirip dan durinya.

2. Importance Performance Analysis (IPA)

Importance-Performance Analysis (IPA) terdiri atas dua komponen, yaitu analisis kuadran dan analisis kesenjangan (gap). Analisis kuadran memetakan atribut yang diplotkan berdasarkan tingkat kepentingan dan kinerja, sedangkan analisis kesenjangan digunakan untuk melihat kesenjangan antara kondisi ideal/harapan responden dari suatu variabel dengan kondisi aktual/kinerja yang dicapai oleh organisasi terkait (Supranto 2004).

3. The House Model

The House Model merupakan konsep yang dibangun dalam menggambarkan usaha organisasi untuk mengubah mimpi menjadi sebuah tindakan. Horovitz dan Ohlsson-Corboz (2007) menyatakan bahwa hal utama yang paling dibutuhkan oleh organisasi adalah sebuah visi inspirasional tentang masa depan organisasi, yaitu sebuah impian dengan batas waktu. Impian dengan batas waktu ini memerlukan pilar-pilar yang dapat menyokong keberadaan dan pencapaiannya. The House Model tersebut dijelaskan melalui Gambar 3. 


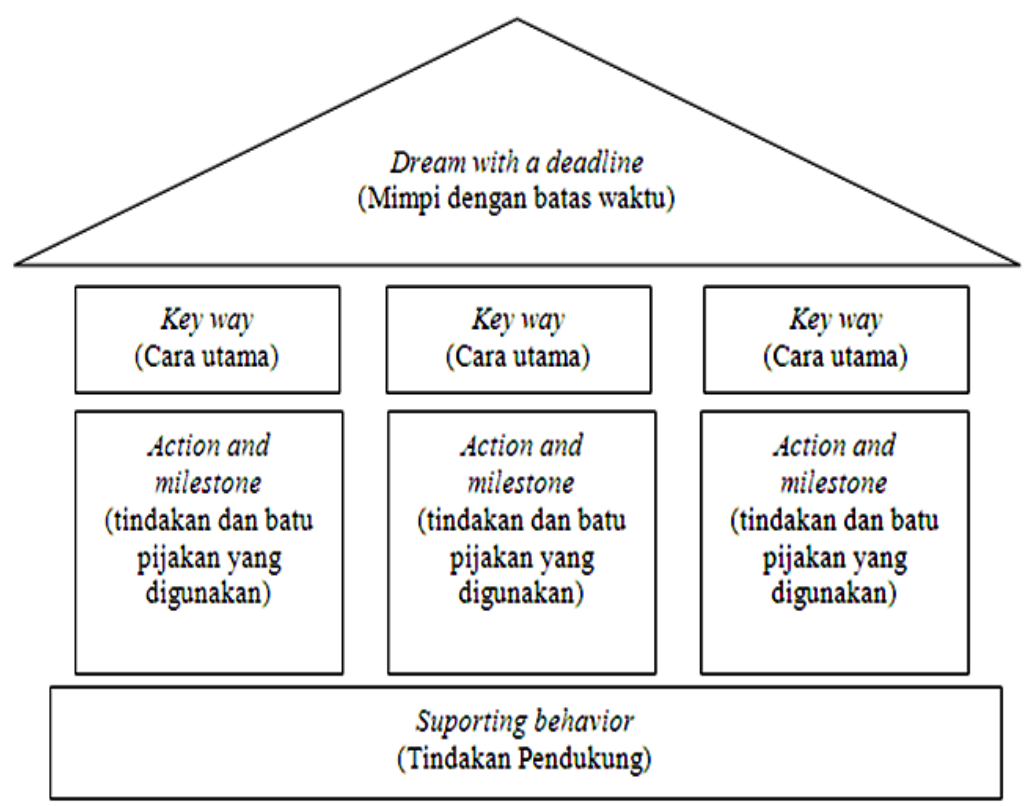

Gambar 3. Kerangka The House Model

\section{Force Field Analysis (FFA)}

Analisis kekuatan lapangan (Force Field Analysis) digunakan secara meluas untuk menginformasikan pembuatan keputusan (Mcshane dan Von Glinow 2007). Metode ini digunakan untuk memperoleh gambaran lengkap yang menyeluruh berbagai kekuatan pendorong dan penghambat yang ada dalam isu utama suatu kebijakan.

\section{Hasil dan Pembahasan}

\section{III.1. Gambaran Umum UKM Kerajinan Kota Depok}

Responden pada penelitian ini adalah UKM kluster kerajinan berjumlah 9 UKM, yang terdiri atas 8 usaha berskala kecil dan 1 usaha berskala menengah. Sebagian besar usaha berskala kecil baru berdiri di bawah 11 tahun, sedangkan usaha berskala menengah yang menjadi responden telah berdiri di atas 20 tahun. Kesembilan UKM dipilih sebagai responden karena berproduksi secara kontinyu, berpengalaman mengikuti pameran dan memiliki keunikan masing-masing produknya. Aset yang dimiliki oleh UKM kerajinan Kota Depok antara lain workshop yang mayoritas masih berbagi ruang dengan rumah pemilik, kendaraan pribadi pemilik yang digunakan juga sebagai kendaraan operasional, serta beberapa mesin. Mesin digunakan hanya sebagai pendukung kegiatan produksi karena mayoritas pekerjaan di UKM kluster ini lebih menuntut ketrampilan tangan dari pengrajin. Mesin yang digunakan antara lain mesin jahit, mesin potong, mesin obras, mesin jiqsaw, mesin amplas, bor, dan scrollsaw. Karakteristik UKM yang menjadi responden dijelaskan pada Tabel 1. 
Tabel 1. UKM kerajinan Kota Depok yang menjadi responden penelitian

\begin{tabular}{lcclcc}
\hline \multicolumn{1}{c}{ Nama UKM } & $\begin{array}{c}\text { Lama } \\
\text { Berdiri }\end{array}$ & $\begin{array}{c}\text { Skala } \\
\text { Usaha }\end{array}$ & \multicolumn{1}{c}{ Jenis Usaha } & $\begin{array}{c}\text { Tenaga } \\
\text { kerja }\end{array}$ & $\begin{array}{c}\text { Omset } \\
\text { (juta) }\end{array}$ \\
\hline Taqqia Craft & 6 & Kecil & Handycraft sulam & $10-20$ & $15-30$ \\
Rajut Ranalya & 6 & Kecil & Handycraft rajutan & 6 & $<15$ \\
Mabela Bonafi & 7 & Kecil & $\begin{array}{l}\text { Handycraft berbahan } \\
\text { batik }\end{array}$ & 10 & $60-75$ \\
Pancuran Art & 10 & Kecil & Kreasi pancuran & 5 & $15-30$ \\
Genta Nada & 8 & Kecil & Pajangan Gantung & 7 & $15-30$ \\
Citra Handycraft & 9 & Kecil & Handycraft sulam & 7 & $30-45$ \\
Dayufa & 15 & Kecil & Kerajinan tas & 7 & $60-75$ \\
Mentari Handycraft & 13 & Kecil & Handycraft dari mute & 6 & $15-30$ \\
Hanimo & 23 & Menengah & Alat peraga TK dan PAUD & 50 & $400-500$ \\
\hline
\end{tabular}

\section{III.2. Permasalahan UKM Kerajinan Kota Depok}

Permasalahan UKM kerajinan di Kota Depok dijelaskan melalui Diagram Ishikawa (fishbone chart). Ekor ikan melambangkan kategori penyebab utama, sedangkan duriduri lain merupakan kategori penyebab pendukung dari permasalahan yang dihadapi UKM. Permasalahan yang dihadapi UKM Kerajinan Kota Depok adalah "Rendahnya kinerja UKM". Permasalahan ini diletakan di kepala diagram ishikawa. Selengkapnya permasalahan UKM kerajinan Kota Depok dapat ditampilkan pada Gambar 4.

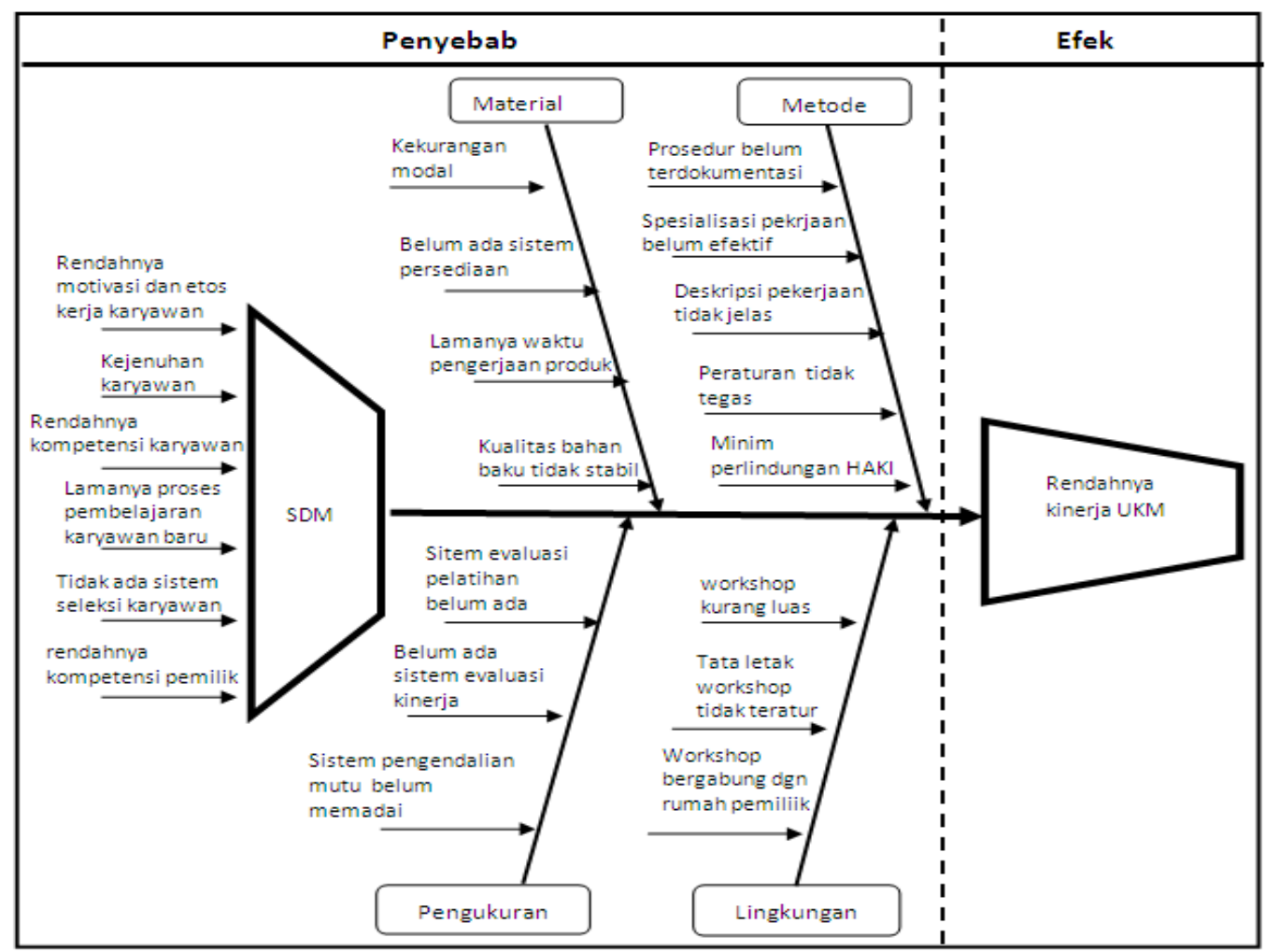

Gambar 4. Diagram Ishikawa UKM Kerajinan di Kota Depok 
Dari Gambar 4 di atas, dapat diketahui bahwa kelompok penyebab utama adalah sumberdaya manusia. Sumberdaya manusia yang dimaksud adalah seluruh pihak yang terlibat dalam organisasi. Penyebab dari kelompok sumber daya manusia (SDM) adalah kurangnya kompetensi manajerial pemilik UKM. Dari sudut pandang karyawan, penyebab dari kategori ini adalah kurangnya pelatihan yang memadai; kurangnya etos kerja dan motivasi pengembangan diri karyawan; lamanya proses pembelajaran karyawan baru; serta tidak ada sistem seleksi dan perekrutan karyawan.

Metode mendeskripsikan cara suatu proses dilakukan dan kebutuhan dari proses tersebut, seperti: prosedur, instruksi dan peraturan. Penyebab dari kategori ini adalah belum ada pendokumentasiaan prosedur, sistem spesialisasi pekerjaan belum efektif, deskripsi pekerjaan tidak jelas, sanksi terhadap pelanggar yang tidak tegas, serta minimnya sistem perlindungan kekayaan intelektual.

Material (material) merupakan seluruh bahan yang diperlukan untuk melakukan suatu proses di organisasi. Material memiliki penyebab primer sebagai berikut: Kekurangan modal, jauhnya letak sumber bahan baku dan sedikit referensi sumber bahan baku, tidak ada sistem pencatatan persediaan dan barang cacat, lamanya jangka waktu pengerjaan kerajinan tangan, dan kualitas bahan baku yang tidak stabil.

Lingkungan merupakan kondisi di sekitar tempat kerja. Penyebab primer dari kategori ini yakni workshop memiliki tata letak tidak teraturd an pencahayaan kurang baik, ruang kerja yang relatif sempit dan kondisi workshop yang masih bergabung dengan rumah pemilik.

Pengukuran (measurement) adalah penyebab yang berhubungan dengan cara pengambilan data dari proses yang dipakai untuk menentukan kualitas proses. Penyebab primer dari kelompok ini adalah belum ada standar pelaksanaan dan sistem pengendalian mutu, belum ada sistem evaluasi pelatihan, serta belum ada evaluasi kinerja dan kelayakan bisnis secara berkala..

Hasil dari analisis diagram ishikawa adalah penyebab utama dari permasalahan UKM berasal dari faktor SDM. Faktor penyebab utama ini akan dirancang langkah perbaikannya dengan cara memasukkan faktor ini menjadi pilar utama dari The House Model.

\section{III.3. Tingkat Kepentingan dan Pencapaian Kinerja UKM}

IPA adalah sebuah teknik analisis statistik deskriptif yang digunakan untuk mengidentifikasi faktor-faktor kinerja penting apa saja yang harus ditunjukkan oleh organisasi dalam memenuhi kepuasan para pengguna jasa mereka (Wong et al. 2011). Analisis ini terdiri atas analisis kuadran dan analisis kesenjangan (gap analysis).

1. Analisis Kuadran

Analisis kuadran berfungsi untuk menunjukan hubungan antara penilaian tingkat kepentingan dengan kinerja yang telah dicapai UKM. Variabel dijabarkan ke dalam diagram cartesius berdasarkan penilaian performance (kinerja) UKM dan importance (kepentingan) dari pemilik UKM. Sumbu $X$ adalah kinerja UKM dan sumbu $Y$ adalah tingkat kepentingan dari pemilik. Hasil selengkapnya ditampilkan pada Tabel 2. 
Tabel 2. Rata-rata skor kepentingan dan kinerja

\begin{tabular}{|c|c|c|c|}
\hline No & Variabel & Kinerja (X) & Kepentingan (Y) \\
\hline 1. & Laporan keuangan & 3.11 & 4.44 \\
\hline 2. & Pencatatan keuangan harian & 3.11 & 4.78 \\
\hline 3. & Sarana prasarana & 3.00 & 4.78 \\
\hline 4. & Standar pelaksanaan produksi & 3.22 & 4.56 \\
\hline 5. & Standar mutu & 3.22 & 4.78 \\
\hline 6. & Sistem pengendalian mutu & 3.22 & 4.78 \\
\hline 7. & Inovasi produk & 3.89 & 4.78 \\
\hline 8. & Inovasi teknik produksi & 3.67 & 4.67 \\
\hline 9. & Target pasar & 3.44 & 4.67 \\
\hline 10. & Promosi produk & 3.89 & 4.78 \\
\hline 11. & Jaringan distribusi & 3.44 & 4.56 \\
\hline 12. & Administrasi SDM & 2.78 & 4.44 \\
\hline 13. & Pelatihan SDM & 3.00 & 4.56 \\
\hline 14. & Sistem kompensasi & 3.67 & 4.78 \\
\hline 15. & Rencana jangka pendek & 3.44 & 4.89 \\
\hline 16. & Rencana jangka menengah & 3.11 & 4.67 \\
\hline 17. & Rencana jangka panjang & 3.22 & 4.67 \\
\hline 18. & Visi usaha terdokumentasi & 2.56 & 4.33 \\
\hline 19. & Misi usaha terdokumentasi & 2.56 & 4.33 \\
\hline 20. & Tujuan usaha & 3.56 & 4.78 \\
\hline 21. & Budaya organisasi & 3.11 & 4.78 \\
\hline \multirow[t]{3}{*}{22.} & Struktur organisasi formal & 2.67 & 4.44 \\
\hline & Jumlah & 70.89 & 102.22 \\
\hline & Rata-rata & 3.23 & 4.65 \\
\hline
\end{tabular}

Nilai-nilai yang dapat dilihat pada Tabel 2 menggambarkan kordinat masingmasing variabel dalam diagram kartesius. Variabel 1 terletak di $(3.11 ; 4.44)$, variabel 2 terletak di $(3.11 ; 4.78)$, dan seterusnya. Rata-rata dari rata-rata skor kinerja $(\overline{\bar{X}})$ adalah sebesar 3.23 sedangkan rata-rata dari rata-rata kepentingan $(\overline{\bar{Y}})$ adalah 4.65. Angka tersebut yang akan digunakan sebagai pembatas sehingga kuadran akan terbagi menjadi empat bagian. Seluruh variabel yang telah ditentukan akan tersebar ke empat bagian dalam kuandran analisis pada Gambar 5.

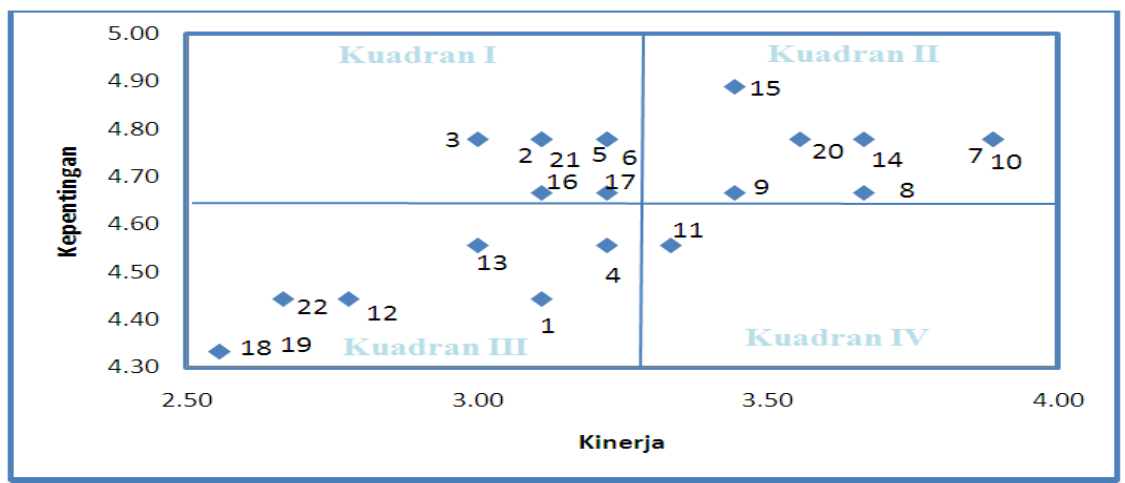

Gambar 5. Analisis kuadran tingkat kepentingan dan kinerja UKM kerajinan

Penyebaran variabel-variabel penelitian dijelaskan sebagai berikut:

a. Kuadran I (Prioritas utama) 
Variabel-variabel di bagian ini memiliki tingkat kinerja di bawah rata-rata tetapi tingkat kepentingan tinggi. Variabel yang masuk ke dalam kuadran I adalah variabel: pencatatan keuangan harian, sarana dan prasarana, standar mutu, sistem pengendalian mutu, rencana jangka menengah, rencana jangka panjang, budaya organisasi.

b. Kuadran II (Pertahankan kinerja)

Variabel-variabel ini memiliki tingkat kepentingan yang tinggi dan kinerja yang diatas rata-rata. Variabel-variabelnya adalah inovasi produk, inovasi teknik produksi, target pasar, promosi produk, sistem kompensasi, rencana jangka pendek, tujuan usaha.

c. Kuadran III (Prioritas rendah)

Variabel-variabel ini memiliki tingkat kepentingan di bawah rata-rata dan kinerjanya juga di bawah rata-rata. Variabelnya adalah variabel: laporan keuangan, standar pelaksanaan produksi, administrasi SDM, pelatihan SDM, visi usaha terdokumentasi, misi usaha terdokumentasi, struktur organisasi formal.

d. Kuadran IV (Kinerja berlebihan)

Variabel-variabel ini memiliki tingkat kepentingan di bawah rata-rata tetapi kinerja di atas rata-rata, sehingga dianggap berlebihan oleh pemilik. Pada kuadran ini, fokus sumber daya dapat dialihkan ke variabel lain yang lebih diprioritaskan. Variabel yang termasuk kuadran ini adalah variabel jaringan distribusi.

\section{Analisis Kesenjangan (Gap)}

Kesenjangan yang dimaksud adalah selisih antara kinerja dengan rata-rata kinerja 22 variabel yang digunakan. Hasil perhitungan tersebut dapat dilihat pada Tabel 3.

Tabel 3. Kesenjangan kinerja pada UKM kerajinan Kota Depok

\begin{tabular}{lcccc}
\hline \multicolumn{1}{c}{ Variabel } & Kinerja $(\boldsymbol{X})$ & $\begin{array}{c}\text { Kinerja rata-rata } \\
(\boldsymbol{X})\end{array}$ & Gap & Kuadran \\
\hline Sarana prasarana (3) & 3.00 & 3.23 & -0.23 & \\
Pencatatan keuangan harian (2) & 3.11 & 3.23 & -0.12 & \\
Rencana jangka menengah (16) & 3.11 & 3.23 & -0.12 & \\
Budaya organisasi (21) & 3.11 & 3.23 & -0.12 & Kuadran I \\
Standar mutu (5) & 3.22 & 3.23 & -0.01 & \\
Sistem pengendalian mutu (6) & 3.22 & 3.23 & -0.01 & \\
Rencana jangka panjang (17) & 3.22 & 3.23 & -0.01 & \\
\hline Rencana jangka pendek (15) & 3.44 & 3.23 & 0.21 & \\
Target pasar (9) & 3.44 & 3.23 & 0.21 & \\
Tujuan usaha (20) & 3.56 & 3.23 & 0.33 & \\
Sistem Kompensasi (14) & 3.67 & 3.23 & 0.44 & Kuadran II \\
Inovasi teknik produksi (8) & 3.67 & 3.23 & 0.44 & \\
Inovasi produk (7) & 3.89 & 3.23 & 0.66 & \\
Promosi produk (10) & 3.89 & 3.23 & 0.66 & \\
\hline Visi usaha terdokumentasi (18) & 2.56 & 3.23 & -0.67 & \\
misi usaha terdokumentasi (19) & 2.56 & 3.23 & -0.67 & \multirow{2}{*}{ Kuadran III } \\
Struktur organisasi formal (22) & 2.67 & 3.23 & -0.56 & \\
Administrasi SDM (12) & 2.78 & 3.23 & -0.45 & \\
\hline
\end{tabular}


Lanjutan Tabel 3.

\begin{tabular}{|c|c|c|c|c|}
\hline Variabel & Kinerja $(X)$ & $\begin{array}{c}\text { Kinerja rata-rata } \\
(X)\end{array}$ & Gap & Kuadran \\
\hline Pelatihan SDM (13) & 3.00 & 3.23 & -0.23 & \\
\hline Laporan Keuangan (1) & 3.11 & 3.23 & -0.12 & Kuadran III \\
\hline Standar Pelaksanaan produksi (4) & 3.22 & 3.23 & -0.12 & \\
\hline Jaringan distribusi (11) & 3.44 & 3.23 & 0.21 & Kuadran IV \\
\hline Jumlah & 70.89 & & & \\
\hline Rata-rata & 3.23 & & & \\
\hline
\end{tabular}

Tabel 3 menunjukan variabel yang memiliki kinerja di bawah rata-rata seluruh variabel adalah variabel yang berada di Kuadran Satu dan Tiga. Kuadran Tiga memiliki nilai kesenjangan tinggi namun tidak menjadi prioritas perbaikan. Perbandingan antara Analisis IPA dengan analisis diagram Ishikawa menunjukan kesalahan yang terjadi pada UKM kerajinan di Kota Depok. Analisis Diagram Ishikawa menyatakan bahwa SDM merupakan permasalahan utama yang menyebabkan rendahnya kinerja UKM. Namun, analisis IPA menyatakan dua variabel SDM termasuk ke dalam Kuadran Tiga yaitu sebagai variabel yang tidak diprioritaskan. UKM kerajinan selama ini sudah cukup sering melakukan pelatihan terhadap SDM, terutama melalui kerja sama dengan Dinas dan lembaga terkait. Namun, kekurangannya adalah tindakan evaluasi dari keberhasilan pelatihan dan materi pelatihan yang sangat jarang diaplikasikan di UKM kerajinan. Kegagalan dalam pengaplikasian materi pelatihan inilah yang menyebabkan timbulnya persepsi bahwa pelatihan bukanlah hal yang dapat menimbulkan efek signifikan dalam perbaikan kinerja UKM.

Totana yang disitasi Ancok (2003) menyatakan bahwa sebuah perusahaan akan memiliki kinerja yang berbeda pada pengelolaan orang yang berbeda, artinya manusia yang berbeda dalam mengelola aset yang sama akan menghasilkan nilai tambah yang berbeda. Analisis IPA menyatakan bahwa pernyataan tersebut belum diterapkan di UKM kerajinan. Hal ini dapat dilihat dari letak variabel administrasi SDM yang merupakan kebijakan-kebijakan dalam pengelolaan SDM berada di Kuadran Tiga. Mayoritas pemilik UKM masih menganggap bahwa aset fisik seperti sarana dan prasaranalah yang menjadi prioritas dalam perbaikan kinerja UKM. Persepsi inilah yang perlu diperbaiki dari UKM kerajinan Kota Depok. Oleh karena itu, selain variabel-variabel yang berada di Kuadran Satu, kedua variabel ini akan diperbaiki dan menjadi pilar dalam rancangan model peningkatan kinerja melalui The House Model.

\section{III.4. Model Peningkatan Kinerja UKM Kerajinan Kota Depok}

The House Model dari penelitian ini akan mengangkat visi usaha terpendam, yaitu bukan lagi hanya tentang mencari keuntungan pribadi saja, melainkan memiliki visi untuk menjadi unit usaha yang dapat menyediakan lapangan pekerjaan atau memberdayakan masyarakat sekitar sehingga memiliki penghasilan yang layak. Visi ini 
diangkat menjadi "atap" dari the house model dan diterjemahkan "Menjadi UKM Kerajinan yang berdaya saing tinggi dan berkelajutan dalam periode 5 tahun". Impian dengan batas waktu ini diharapkan dapat memberikan tantang baru kepada pelaku usaha yang memiliki motivasi rendah dan sudah merasa puas dengan kondisi UKM-nya saat ini.

Pilar-pilar yang menyokong "atap" The House Model berasal dari pengembangan analisis diagram Ishikawa dan IPA. Permasalahan utama dalam Diagram Ishikawa akan dijadikan pilar utama yaitu "mengembangkan tim (SDM) terbaik". Pilar-pilar pelengkap diperoleh dari variabel pada Kuadran I analisis IPA. Variabel ini membangun dua pilar pelengkap, yaitu "prima administrasi" serta "peningkatan kualitas produk dan proses produksi". Pilar terakhir adalah pilar pemasaran terintegrasi. Keberhasilan dari pilarpilar pelengkap ditentukan oleh pencapaian dari pilar utama karena untuk mencapai pilar pelengkap ini dibutuhkan tim SDM yang handal. Variabel rencana jangka menengah dan jangka panjang membangun fondasi dasar The House Model, yaitu konsisten dan komitmen menjalankan strategi yang terintegrasi dan berkesinambungan. The House Model ini lebih lengkap dijelaskan melalui Gambar 6.

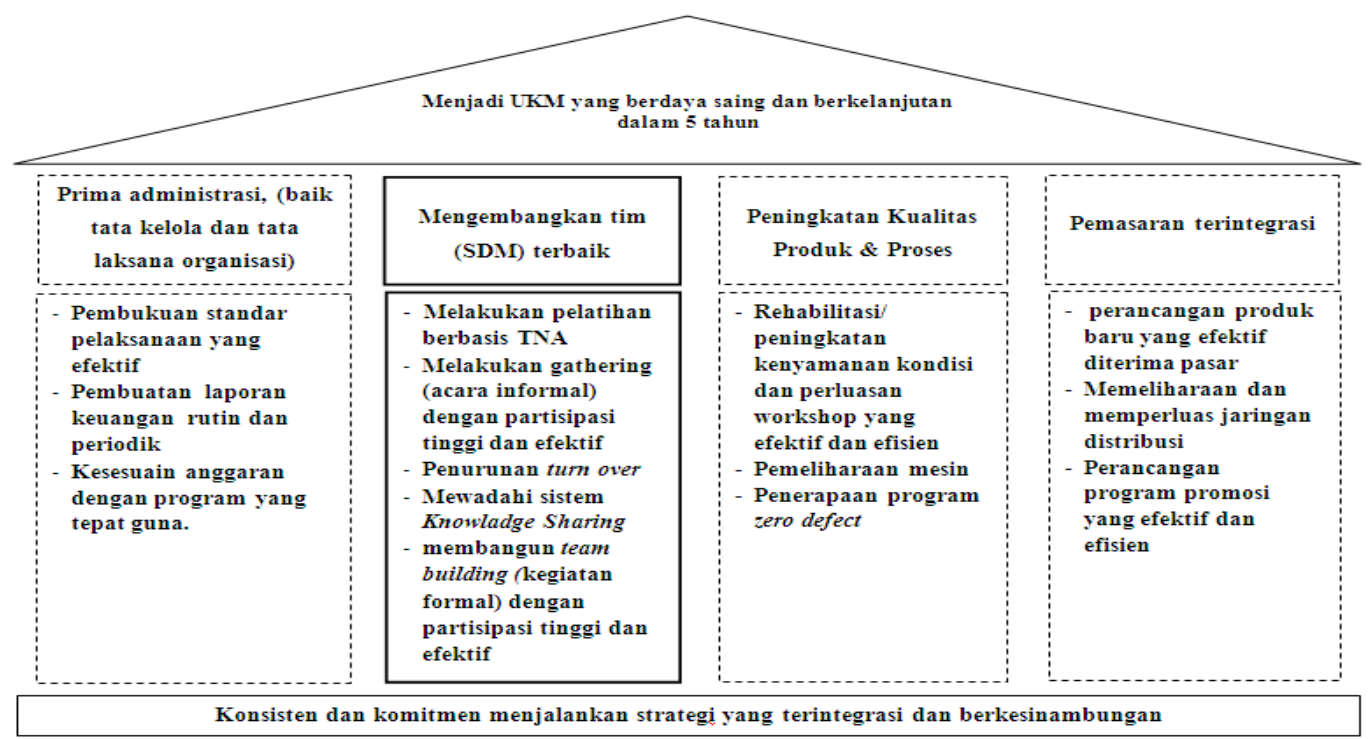

Gambar 6. The House Model UKM kerajinan Kota Depok

III.5. Implikasi Manajerial

Peran UKM dalam menjadi tulang punggung perekonomian nasional belum dapat memberikan hasil yang optimal. Mimpi dan upaya yang dilakukan UKM seperti yang digambarkan melalui The House Model, memiliki factor hambatan yang bersifat internal dan ekternal. Namun, UKM juga memiliki faktor pendorong yang dapat digunakan untuk berkembang dan berkinerja lebih baik. Faktor-faktor tersebut dapat dilihat

pada

Tabel 4. 
Tabel 4. Force Field Analysis pada UKM Kerajinan Kota Depok

\begin{tabular}{|c|c|}
\hline Faktor Pendorong & Faktor Penghambat \\
\hline 1. Ketersediaan kuantitas SDM & 1. Rendahnya pengawasan dan motivasi SDM \\
\hline 2. Keunikan eproduk dan focus pada produk spesifik & 2. Kurangnya pengawasan \\
\hline 3. Akses lokasi dan infrastruktur & $\begin{array}{l}\text { 3. Keterbatasan penggunaan teknologi di } \\
\text { pemasaran }\end{array}$ \\
\hline $\begin{array}{l}\text { 4. Bantuan dari berbagai instansi tentang } \\
\text { permodalan }\end{array}$ & 4. Birokrasi yang terlalu rumit \\
\hline 5. Hubungan kekerabatan yang erat & 5. Sanksi internal kurang tegas \\
\hline 6. Hirarki manajerial yang pendek & 6. Deskripsi pekerjaan belum jelas \\
\hline
\end{tabular}

Permasalahan usaha kecil dan menengah dari sisi internal seperti yang telah dijelakan melalui diagram Ishikawa dapat diatasi melalui komitmen, konsistensi terhadap aturan dan rencana yang dibuat serta partisipasi dari seluruh pihak untuk mengubah dan berkembang bersama UKM. Rancangan peningkatan kinerja UKM yang dapat dilihat melalui The House Model dapat diaplikasikan dalam upaya perbaikan internal. Namun, upaya perbaikkan tersebut perlu melibatkan pihak diluar UKM pula karena UKM sendiri masih kekurangan pengalaman dan modal. Pembinaan dan pengembangan tersebut dapat dilakukan dari Usaha berskala besar dalam bentuk program mitra binaan. Usaha besar (perusahaan) dapat membantu dalam pembinaan media promosi untuk meningkatkan akses pasar, daya saing pemasaran, dan perbantuan terhadap permodalan. Sedangkan, dari pihak pemerintah diharapkan dapat memfasilitasi UKM dan mempermudah birokrasi.

\section{Kesimpulan}

Hasil analisis Diagram Ishikawa menyatakan bahwa permasalahan utama UKM adalah SDM. Hasil ini didukung oleh analisis SEM yang menyatakan bahwa modal insani memiliki pengaruh positif dan signifikan terhadap kinerja UKM dengan modal sosial sebagai variabel perantara. Hasil dari kedua alat analisis bertentangan dengan hasil IPA. Pemilik UKM beranggapan bahwa sarana prasarana memiliki prioritas tertinggi untuk diperbaiki. Oleh karena itu, kesalahan persepsi inilah yang diperbaiki melalui rancangan peningkatan kinerja UKM kluster kerajinan Kota Depok melalui The House Model. Model peningkatan kinerja yang dijelaskan melalui The House Model menetapkan "menjadi UKM kerajinan yang berdaya saing dan berkelanjutan dalam 5 tahun" sebagai impian utama UKM kerajinan di Depok. Impian ini dibangun dengan "pengembangan tim (SDM) terbaik" sebagai pilar utama.

Pengaplikasian The House Model memiliki faktor pendorong dan penghambat. Faktor pendorong model peningkatan kinerja UKM tersebut adalah ketersediaan kuantitas SDM; keunikan produk; akses dan infrastruktur yang mendukung; bantuan permodalan dari berbagai pihak; pengembangan produk yang spesifik hubungan kekerabatan yang erat dan hierarki manajerial yang pendek. Di sisi lain, faktor penghambat model peningkatan kinerja UKM kerajinan Kota Depok adalah rendahnya kompetensi dan motivasi SDM; kurangnya pengawasan terhadap standar pelaksanaan; masih terbatasnya penggunaan teknologi untuk pemasaran; rendahnya kemauan 
pemilik untuk mengakses informasi permodalan; belum ada deskripsi pekerjaan yang jelas; sanksi kurang tegas; serta rumitnya birokrasi.

\section{Daftar Pustaka}

Ancok D. 2003. Modal Sosial Dan Kualitas Masyarakat [Internet]. Rapat Majelis Guru Besar Universitas Gadjah Mada. Jogjakarta (ID): Universitas Gadjah Mada. [diunduh 2013 Maret 20]. Tersedia pada: http://ancok.staff.ugm.ac.id/file/modal sosialdan kualitas masyarakat.pdf.

Dokko G. 2004. What you know or who you know, human and social capital as deteterminants of individual performance [Disertasi]. Pennsylvania (US): University of Pennsylvania.

Horovitz J, Ohlsson-Corboz AV. 2007. A Dream with a Deadline: Turning Strategy into Action. Harlow [GB]: FT Prentice Hall.

Indriastuti M, Arifah DA. 2008. Peningkatan kinerja UKM dengan pengelolaan Intellectual Capital dan Inovasi. Jurnal Bisnis, Akutansi dan Manajemen. 1(1): 649-662.

Kertati. 2012. Membangun tindakan berbagai pengetahuan afektif rasional melalui modal sosial dan pembelajaran organisasi untuk meningkatkan kinerja bisnis. [Disertasi]. Semarang (ID): Universitas Diponegoro.

Mcshane SL, Von Glinow. 2007. Organizational Behavior: Essentials. United State of America (US): McGraw-Hill.

Nahapiet J, Ghoshal S. 1998. Social capital, intellectual capital, and the organizational advantage. Academic of Management Review. 23(2): 242-266.

Nishantha B. 2011. The relationship between human capital, social capital, and firm growth of small enterprises in Sri Langka. International Research Coference on Management and Finance. Colombo (SL): University of Colombo.

[Pemkot Depok] Pemerintah Kota Depok. 2012. Laporan pertanggungjawaban walikota Depok Tahun 2012.

Prawirosentono S. 2007. Filosofi Terbaru tentang Manajemen Terpadu Abad 21, Kiat Membangun Bisnis Kompetitif. Jakarta (ID): Bumi Aksara.

Stam W, Elfring T. 2008. Entrepreneurial orientation and new venture performance: the moderating role of intra and extraindustry social capital. Academic of Management Journal. 51 (1): 97-111.

Sudarno. 2012. Kontribusi usaha mikro, kecil, dan menengah (UMKM) dalam penyerapan tenaga kerja. Jurnal Penelitian dan pengembangan Humanoria. 9(1):68-76.

Supranto J. 2004. Analisis Multivariat, Arti dan Interpretasi. Jakarta (ID): Rineka Cipta.

Tambunan T. 2009. UMKM di Indonesia. Cetakan Pertama. Bogor (ID): Ghalia Indonesia.

Wirawan. 2009. Evaluasi Kinerja Sumber Daya Manusia, Teori Aplikasi dan Penelitian. Jakarta (ID): Salemba Empat.

Wong MS, Hideki N, George P. 2011. The use of impotance-performance analysis (IPA) in evaluating Japan's e-government services. Journal of Theoretical and Applied Electronic Commerce Research. 6(2): 17-30. 